\title{
IMPLEMETASI DATA WAREHOUSE PADA BAGIAN PEMASARAN PERGURUAN TINGGI
}

\author{
Eka Miranda; Rudy; Eli Suryani \\ Information Systems Department, School of Information Systems, Binus University \\ Jln. K.H. Syahdan No. 9, Palmerah, Jakarta Barat 11480 \\ ekamiranda@yahoo.com
}

\begin{abstract}
Transactional data are widely owned by higher education institutes, but the utilization of the data to support decision making has not functioned maximally. Therefore, higher education institutes need analysis tools to maximize decision making processes. Based on the issue, then data warehouse design was created to: (1) store large-amount data; (2) potentially gain new perspectives of distributed data; (3) provide reports and answers to users' ad hoc questions; (4) perform data analysis of external conditions and transactional data from the marketing activities of universities, since marketing is one supporting field as well as the cutting edge of higher education institutes. The methods used to design and implement data warehouse are analysis of records related to the marketing activities of higher education institutes and data warehouse design. This study results in a data warehouse design and its implementation to analyze the external data and transactional data from the marketing activities of universities to support decision making.
\end{abstract}

Keywords: analysis tools, decision making, higher education institutes, marketing, data warehouse, external data, transactional data

\begin{abstract}
ABSTRAK
Data traksaksional banyak dimiliki oleh perguruan tinggi, tetapi pemanfaatannya untuk mendukung pengambilan keputusan belum maksimal. Oleh karena itu, perguruan tinggi membutuhkan alat bantu analisis untuk memaksimalkan pengambilan keputusan. Berdasarkan permasalahan ini, dibuat desain data warehouse untuk: (1) menyimpan data jumlah besar; (2) mendapatkan sudut pandang baru dari sebaran data; (3) memberikan pelaporan dan jawaban dari pertanyaan pengguna yang bersifat ad hoc; (4) melakukan analisis data kondisi eksternal dan data transaksional dari kegiatan pemasaran perguruan tinggi karena pemasaran adalah salah satu bagian pendukung dan merupakan ujung tombak dari perguruan tinggi. Metode untuk mendesain dan mengimplementasi data warehouse terdiri atas analisis record yang terkait dengan kegiatan pemasaran perguruan tinggi, dan desain data warehouse. Hasil penelitian ini berupa desain data warehouse serta implementasinya untuk menganalisis data kondisi eksternal dan data transaksional dari kegiatan pemasaran perguruan tinggi untuk mendukung pengambilan keputusan.
\end{abstract}

Kata kunci: alat bantu analisis, pengambilan keputusan, perguruan tinggi, pemasaran, data warehouse, data kondisi eksternal, data transaksional 


\section{PENDAHULUAN}

Perguruan tinggi perlu memanfaatkan secara optimal sumber daya yang dimilikinya untuk dapat bersaing. Dalam persaingan yang ketat ini perguruan tinggi dituntut untuk bertindak secara pintar dalam mendapatkan siswa baru (Rudy et al., 2010). Sumber daya dalam hal ini infrastruktur, fasilitas, orang, data serta pengetahuan haruslah dapat digunakan untuk meningkatkan keunggulan dalam bersaing. Seiring dengan tantangan dan peluang yang dihasilkan dari perkembangan ini, institusi pendidikan seharusnya memiliki kemampuan yang baru dalam memanfaatkan kekayaan informasi yang ada. Sehingga pemasaran tidak hanya dituntut menjadi sekedar fungsi taktis tetapi juga strategis, sehingga pemasaran harus memiliki sesuatu yang komprehensif dan relevan dengan kondisi terkini (Rizal dan Furinto, 2009).

Membangun dan mengimplementasikan strategi pemasaran yang tepat untuk berbagai tawaran yang ada menjadi tantangan setiap saat bagi pemasaran institusi pendidikan dan perlu ditingkatkan dari masa ke masa. Untuk membangun strategi pemasaran dibutuhkan kemampuan analisis, data eksternal dan internal yang digunakan dengan optimal. Analisis yang tidak maksimal salah satunya karena tidak semua data baik data eksternal dan internal telah dioptimasi untuk menghasilkan suatu pengetahuan yang bermanfaat bagi manajemen dalam pengambilan keputusan. Data dapat diproses menjadi informasi dan kemudian dapat didistribusikan untuk mendukung kegiatan operasional seharihari yang nantinya dapat juga diolah lebih lanjut dan digunakan untuk kegiatan pengambilan keputusan.

Hambatan yang sering dialami adalah pada kenyataannya tidak semua data terintegrasi sehingga terkadang informasi yang dihasilkan tidak lengkap dan akurat. Pengembangan data warehouse ditujukan untuk mengintegrasikan, menggali dan membuat intisari informasi yang penting dari data yang tersebar. Data warehouse bukan hanya suatu arsip atau fasilitas penyimpanan data, data warehouse harus dengan cerdas dirancang untuk berisi informasi dan data yang penting untuk mendukung memecahkan masalah secara aktif. Data warehouse dikembangkan untuk mempertemukan suatu permintaan bagi Manajemen Informasi dan Analisis yang tidak bisa dijumpai pada database. Aplikasi database tidak mampu untuk mempertemukan kebutuhan ini untuk beberapa pertimbangan: (1) pengolahan pelaporan data yang banyak/besar dapat mengurangi waktu tanggap aplikasi database; (2) perancangan aplikasi database tidaklah dioptimalkan untuk analisis informasi dan pelaporan; (3) kebanyakan organisasi mempunyai lebih dari satu aplikasi database, sehingga pelaporan secara keseluruhan organisasi tidak bisa didukung dari sistem tunggal; (4) pengembangan laporan pada aplikasi database sering memerlukan program komputer spesifik yang mahal. Aktifitas lebih lanjut kemudian adalah analisis informasi dan data yang ada di data warehouse, yang memungkinkan untuk menampilkan dan menganalisis informasi dari berbagai sudut pandang (dimensi).

Dari kasus implementasi data warehouse pada pemasaran perguruan tinggi diformulasikan beberapa masalah, yaitu: (1) perguruan tinggi memiliki banyak data tapi kekurangan informasi berkualitas; (2) diperlukannya efisiensi waktu dan proses untuk menghasilkan informasi yang terintegrasi yang dibutuhkan dalam menganalisis dan mengambil keputusan; (3) diperlukan perangkat analitik yang kemudian digunakan secara optimal untuk mendukung pengambilan keputusan.

Tujuan dari penulisan artikel ini adalah untuk menjelaskan bagaimana data warehouse diimplementasikan pada bagian pemasaran perguruan tinggi terkait dengan analisis terhadap data kegiatan pemasaran untuk mendapatkan informasi yang terintegrasi dari seluruh kegiatan pemasaran, sehingga menghasilkan pengetahuan yang utuh dan menyeluruh untuk mengetahui kinerja pemasaran perguruan tinggi. 


\section{METODE}

Membuat data warehouse tidak sekedar memindahkan data opersional ke dalam data warehouse. Memindahkan data dari beberapa sumber berpotensi menimbulkan masalah besar terutama terkait dengan isu tidak konsistennya data. Data warehouse tidak hanya digunakan dalam melakukan loading, integrasi, dan menyimpan data dalam jumlah besar, tapi juga berpotensi untuk mendapatkan sudut pandang baru dari sebaran data, dan memungkinkan untuk memberikan pelaporan dan jawaban dari pertanyaan pengguna yang bersifat ad hoc secara cepat dan lebih baik.

Secara umum tahapan yang dilakukan untuk desain dan implementasi data warehouse pada studi ini terdiri dari: pertama, analisis data yang terkait dengan pemasaran perguruan tinggi; kedua, mendesain dan membangun data warehouse. Lebih detailnya, membangun data warehouse terdiri atas beberapa tahapan berikut:

\section{Identifikasi Sumber Data}

Langkah pertama sebelum mulai mengembangkan data warehouse yaitu identifikasi sumber data. Kita perlu mencari tahu data yang dibutuhkan untuk diletakkan ke dalam data warehouse.

\section{Membangun ETL (Extraction, Transformation, Loading) Tool}

Setiap data warehouse memiliki data yang berbeda persyaratan. Oleh karena itu, ETL tool yang sesuai adalah solusi yang lebih baik untuk memenuhi persyaratan.

\section{Ekstraksi}

Kita perlu menentukan sistem database yang akan digunakan dan juga mencari tahu data apa yang diperlukan sebelum mendapatkannya. Penurunan biaya perangkat keras dan penyimpanan telah mengatasi masalah pada menghindari duplikasi data dan juga kekhawatiran pada kurangnya ruang penyimpanan sebagai tempat penyimpanan data yang berlebihan atau yang tidak diperlukan. Namun, mungkin tidak ada alasan untuk menyimpan data yang tidak diperlukan dan telah diidentifikasi tidak berguna dalam proses pengambilan keputusan. Oleh karena itu, diperlukan untuk mendapatkan hanya ekstrak data yang relevan sebelum membawa ke data warehouse (Mallach, 2000).

\section{Transformasi}

Setelah penggalian data dari berbagai sumber, transformasi dibutuhkan untuk menjamin konsistensi data. Agar mengubah data ke dalam data warehouse dengan benar, perlu diketahui cara pemetaan bidang sumber data eksternal ke data warehouse. Transformasi dapat dilakukan selama ekstraksi data atau saat memuat data ke dalam data warehouse. Integrasi ini bisa menjadi masalah yang kompleks ketika jumlah sumber data menjadi lebih besar.

\section{Loading}

Setelah proses penggalian, mengubah dan pembersihan dilakukan, data diambil ke dalam data warehouse. Pemuatan data dapat dikategorikan ke dalam dua jenis; pemuatan data yang saat ini ada dalam database operasional dan pemuatan pembaruan data warehouse dari perubahan yang telah terjadi dalam database operasional. Untuk menjamin kesegaran data, data warehouse perlu terus memperbaharui datanya. Banyak persoalan yang perlu dipertimbangkan terutama saat memuat data yang sudah diperbaharui. Sementara saat melakukan pembaruan data warehouse, perlu dipastikan bahwa tidak ada data yang dilepaskan serta overhead minimum selama proses scanning file yang ada. 
Gambar 1 di bawah ini merangkum proses pembangunan data warehouse. Selanjutnya Gambar 2 berikut memuat skema arsitektur data warehouse (Vercellis, 2009, p.51-52):

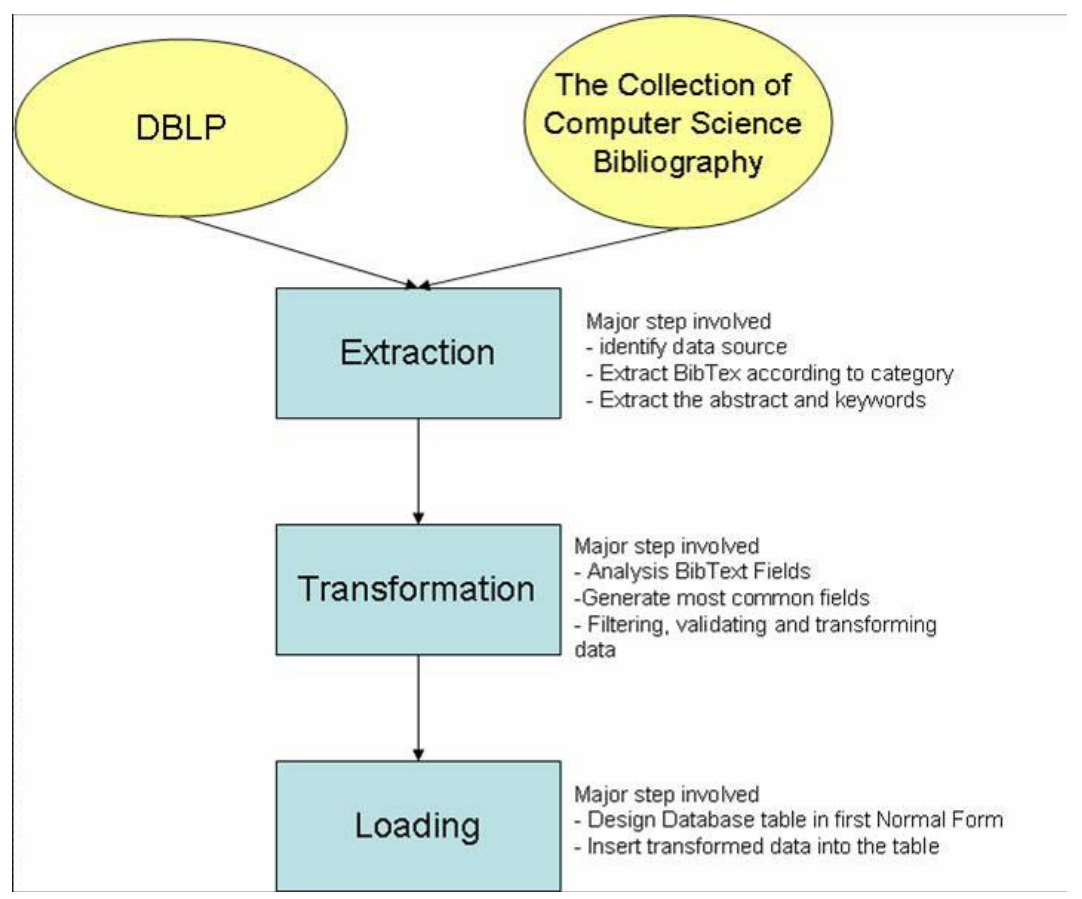

Gambar 1. Tahap-tahap membangun data warehouse (Teh Ying Wah et al., 2007).

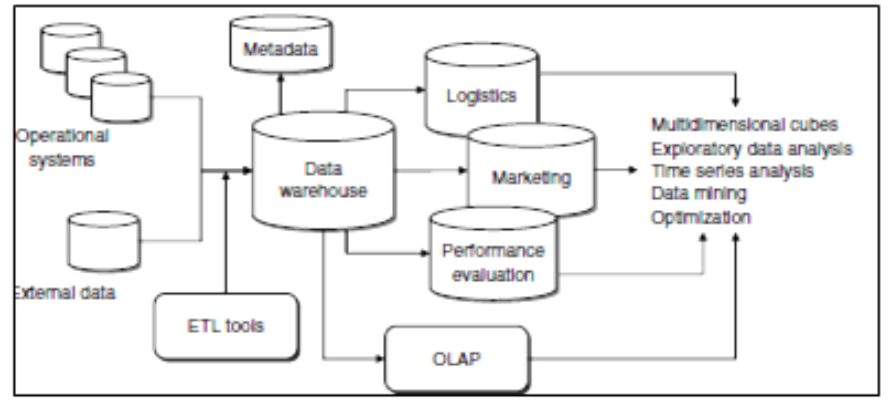

Gambar 2. Arsitektur dan fungsi data warehouse.

Data warehouse bersama dengan data mart tambahan yang berisikan data dan fungsi yang dapat diakses, ditampilkan dan diubah. Pengakuisisian data disebut sebagai proses Extract transform Load (ETL), yang memungkinkan data diseleksi, ditransformasi dan disimpan ke dalam data warehouse.

\section{Star Schema}

Star schema merupakan paradigma modeling yang paling banyak digunakan, dimana di dalamnya mengandung antara lain sebuah tabel pusat yang besar tanpa adanya data redundancy di dalamnya, yang biasa disebut dengan tabel fakta. Selain itu, di dalam star schema juga terdapat satu set tabel yang lebih kecil, yang biasa disebut dengan tabel dimensi. Berikut adalah beberapa karakteristik utama dari star schema: (1) pusat dari star schema adalah tabel fakta; (2) tabel fakta 
berisi indikator-indikator kinerja pokok; (3) objek-objek informasi dan waktu adalah kunci utama tabel fakta; (4) tabel-tabel yang ada di sekeliling tabel fakta adalah tabel dimensi; (5) tabel dimensi berisi data mengenai objek-objek informasi atau waktu; (6) tabel fakta dan tabel dimensi direlasikan dengan key yang ada; (7) diimplementasikan menggunakan teknologi relational database.

\section{HASIL DAN PEMBAHASAN}

\section{Pengumpulan dan Analisis Data}

Proses pemasaran perguruan tinggi yang dilakukan oleh unit pemasaran, kegiatan pemasaran perguruan tinggi beserta atributnya adalah sebagai berikut (Gambar 3):

\section{Mendesain dan Membangun Data Warehouse}

Termasuk di dalam tahap desain data warehouse ini adalah mendesain arsitektur logikal data warehouse (Gambar 5), dan merencanakan sumber data serta dimensional data modeling dalam bentuk star schema. Pada proses pendaftaran, calon mahasiswa diminta memberikan beberapa informasi pada formulir pendaftaran, seperti (Gambar 4):

\section{Dimensional Data Modeling}

Skema yang digunakan untuk membuat data model adalah star schema, di mana terdapat satu fact table dan beberapa dimension table. Menggunakan star schema memungkinkan analisis data dari berbagai dimensi. Fact table merupakan tabel yang digunakan untuk menghubungkan data yang terkait digunakan dalam aktifitas evaluasi akademik siswa. Dimension table adalah tabel yang berisi data yang menampilkan pandangan dari berbagai sudut pandang. Dengan adanya dimension table memungkinkan untuk membuat laporan yang bersifat dinamis dari berbagai sudut pandang.

Skema bintang memiliki beberapa tabel fakta, yaitu: (1) kegiatan promosi; (2) kegiatan pemasaran; (3) pendaftaran. Tabel dimensi yang digunakan terdiri dari: (1) dimensi gelombang; (2) propinsi; (3) kota; (4) waktu; (5) periode; (6) jenis kegiatan; (7) sekolah; (8) semester; (9) jurusan. Skema bintang untuk kegiatan promosi dan pemasaran dapat dilihat pada Gambar 6, sementara untuk pendaftaran pada Gambar 7.

\section{Layar Tampilan Informasi dari Analisis Informasi yang Dibutuhkan}

Berikut adalah beberapa rancangan layar grafikal yang dibuat berdasarkan kebutuhan yang telah didefinisikan:

\section{Kegiatan Pemasaran dan Promosi}

Berikut adalah rancangan antar muka untuk menampilkan Jumlah peserta yang hadir per kegiatan dan atau kegiatan promosi yang dilakukan (Gambar 8 -10). Berikut adalah rancangan tampilan untuk mengetahui Perbandingan jumlah peserta yang hadir dengan jumlah formulir yang terjual per kegiatan dan atau kegiatan promosi yang dilakukan (Gambar 11).

\section{Pendaftaran}

Berikut adalah rancangan antar muka untuk menampilkan persentase pendaftar berdasarkan jenis kegiatan (Gambar 12) dan asal sekolah (Gambar 13). 


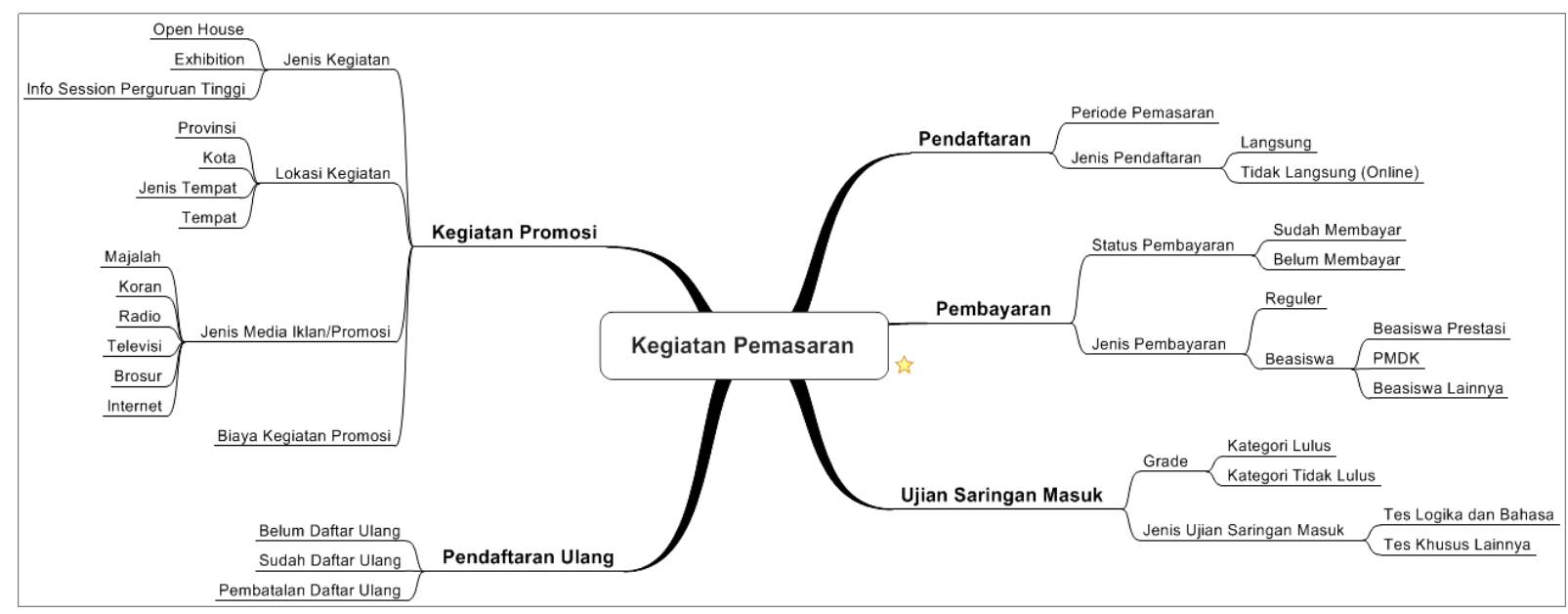

Gambar 3. Pemetaan atribut kegiatan pemasaran perguruan tinggi.

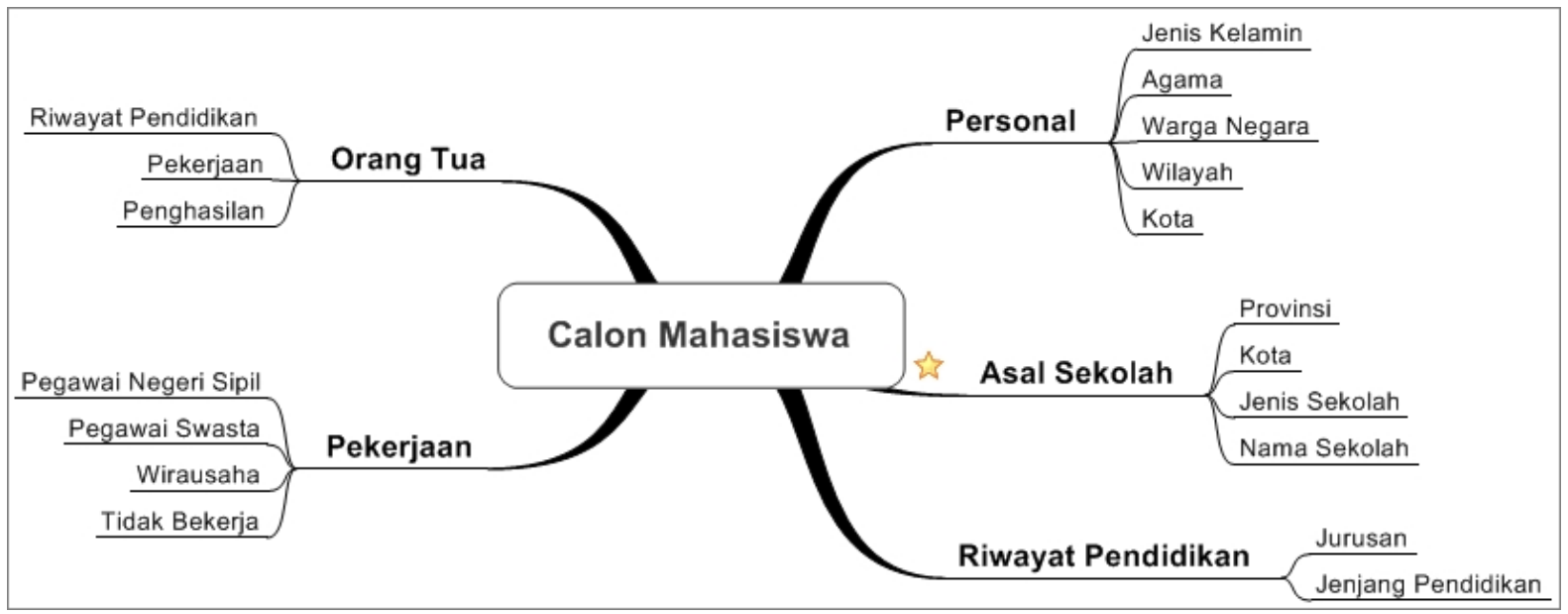

Gambar 4. Pemetaan atribut calon mahasiswa perguruan tinggi.

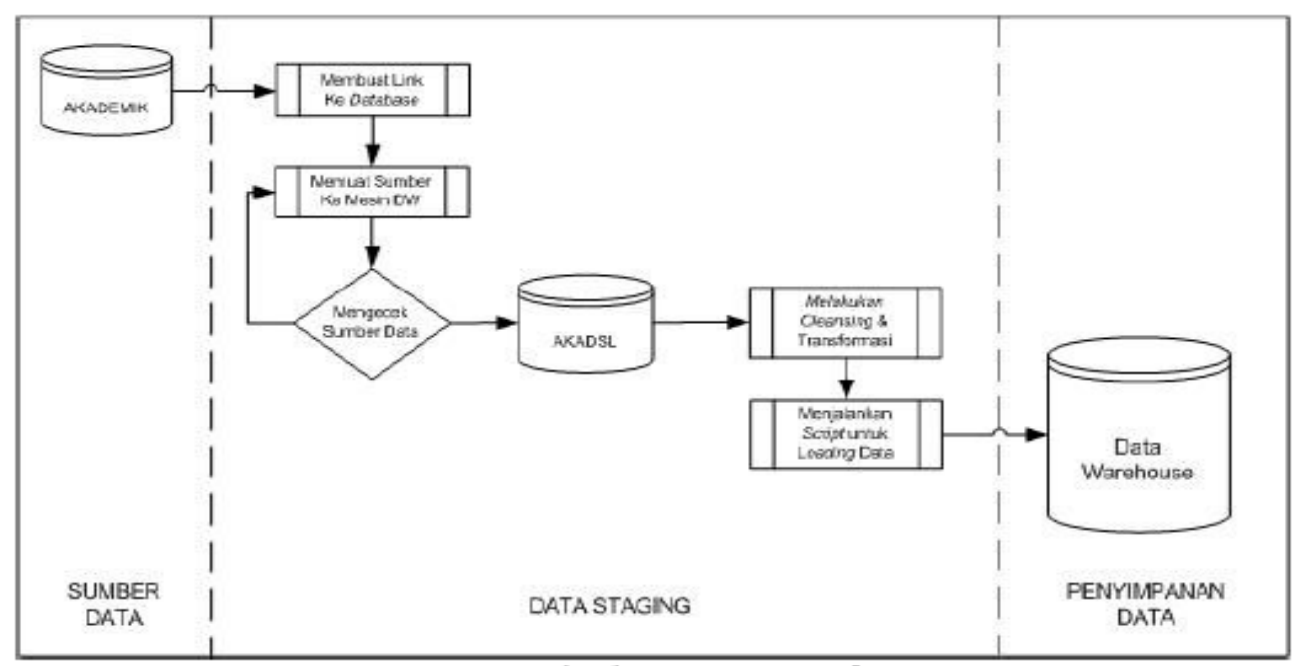

Gambar 5. Arsitektur logikal data warehouse. 


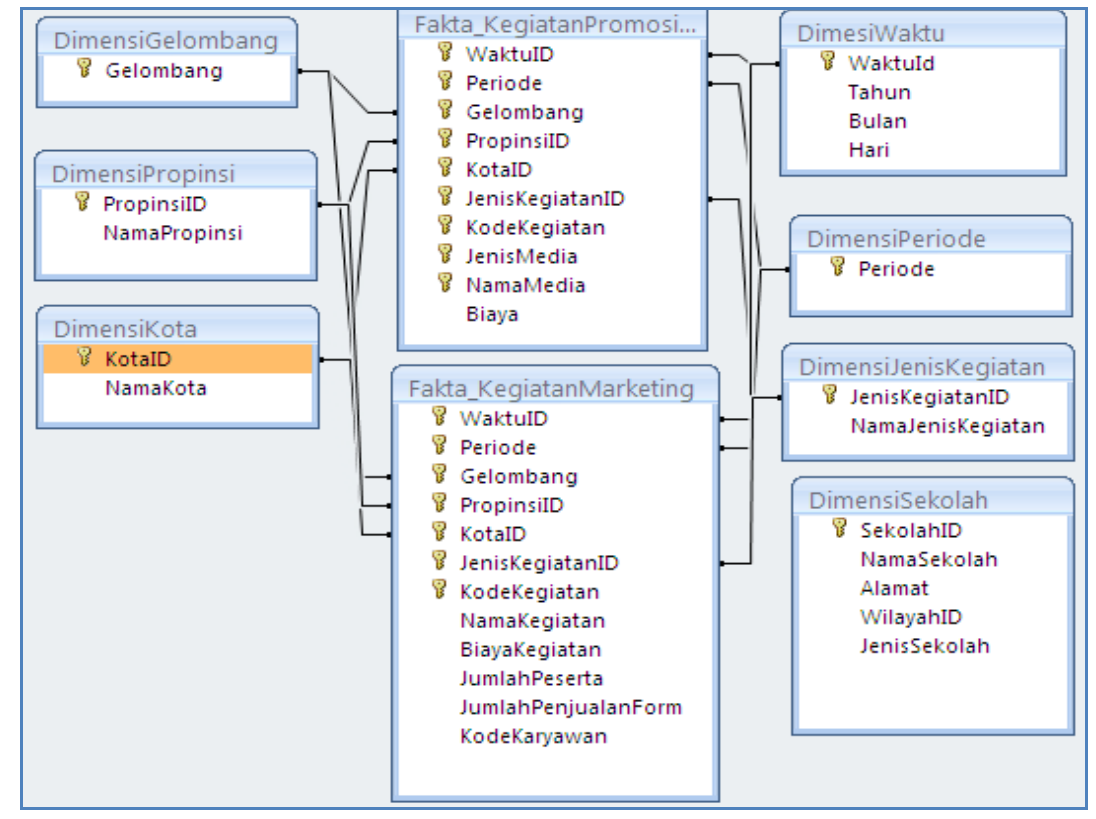

Gambar 6. Skema bintang kegiatan promosi dan pemasaran.

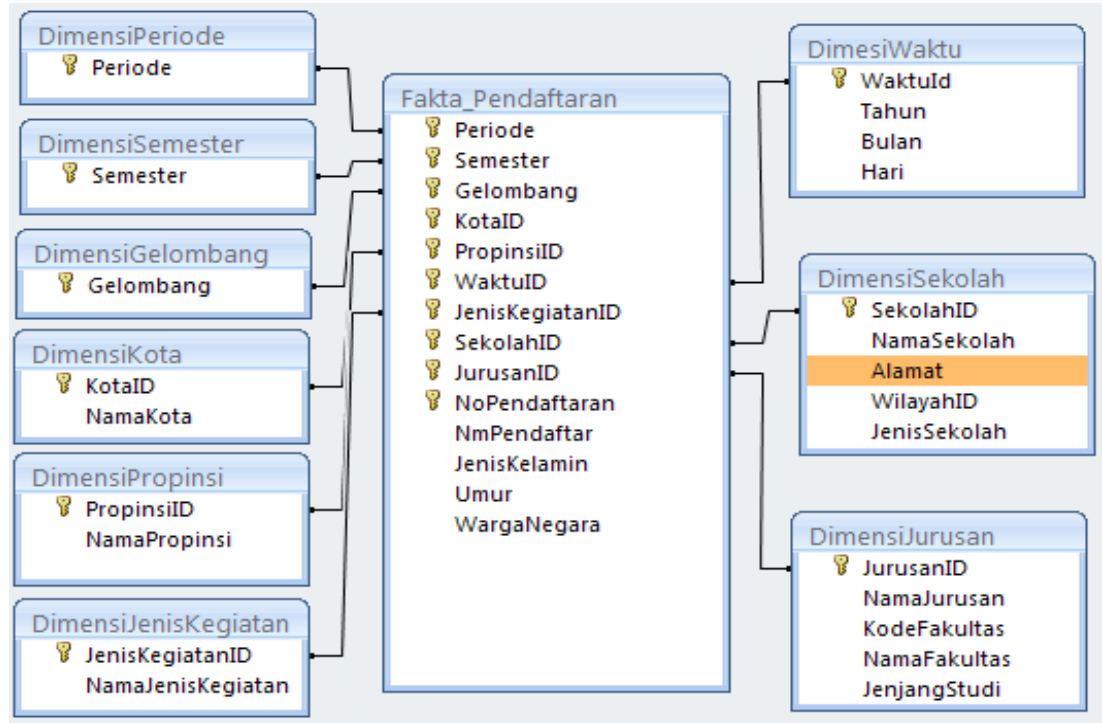

Gambar 7. Skema bintang kegiatan pendaftaran.

\begin{tabular}{|c|c|c|c|c|}
\hline Periode & 2010 & & $\nabla$ & \\
\hline Gelombang & 3 & & .7 & \\
\hline KEGIATAN - & & \#PESERTA & & \#FORMULIR TERJUAL \\
\hline Exhibition & & 32 & & 15 \\
\hline Joint Event & & 26 & & 12 \\
\hline Seminar & & 106 & & 72 \\
\hline Grand Total & & 164 & & 99 \\
\hline
\end{tabular}

Gambar 8. Rancangan antar muka informasi perbandingan jumlah peserta dan formulir terjual. 


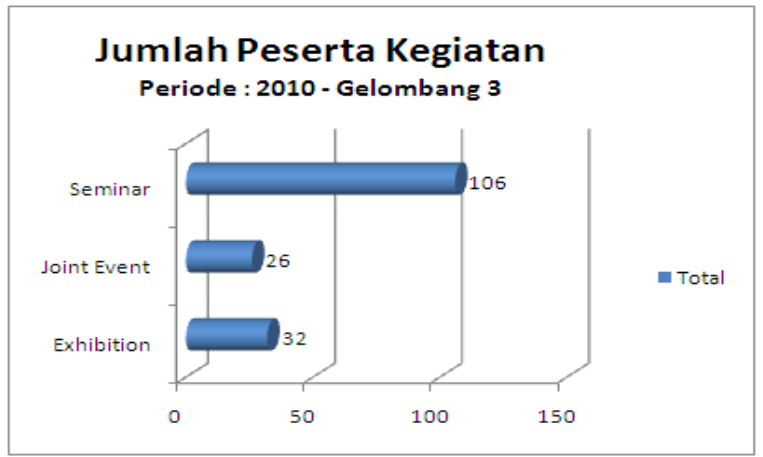

Gambar 9. Rancangan antar muka informasi jumlah peserta.

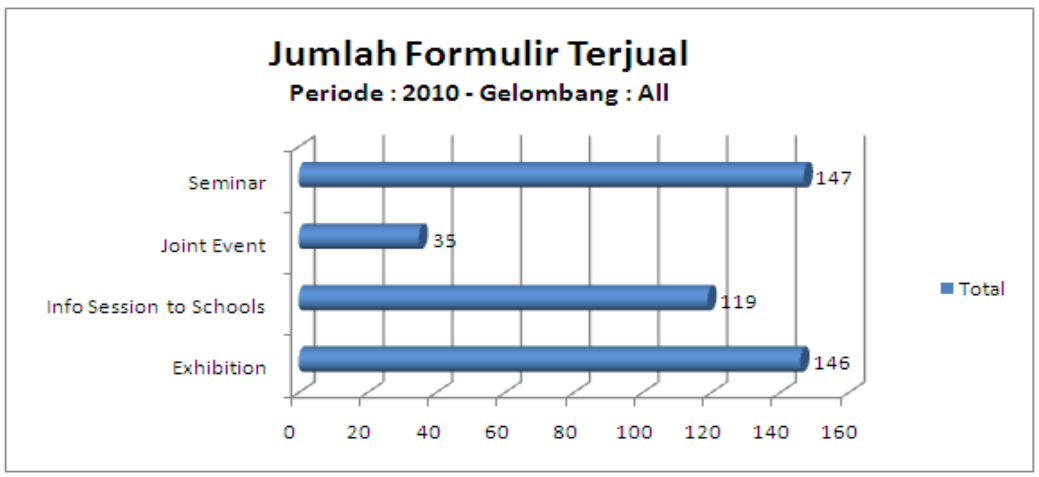

Gambar 10. Rancangan antar muka informasi jumlah formulir terjual.

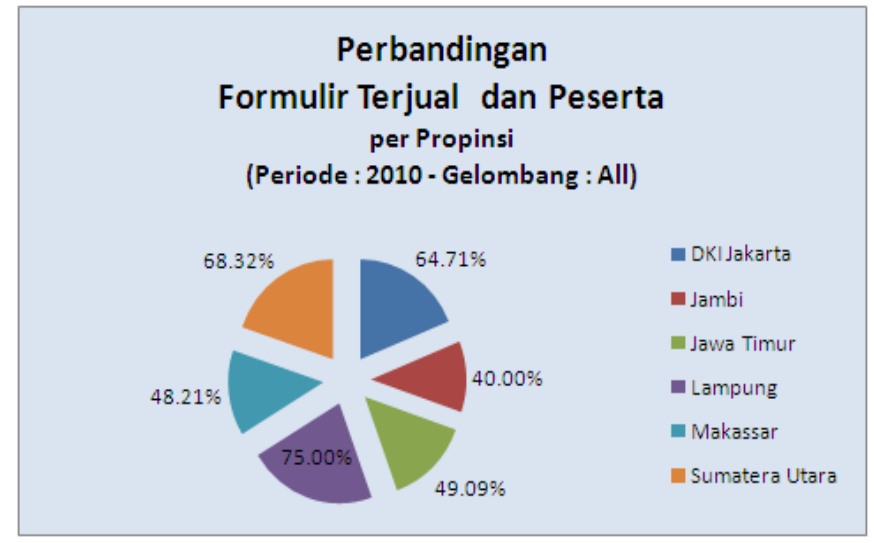

Gambar 11. Rancangan antar muka informasi perbandingan jumlah formulir terjual dan jumlah peserta. 


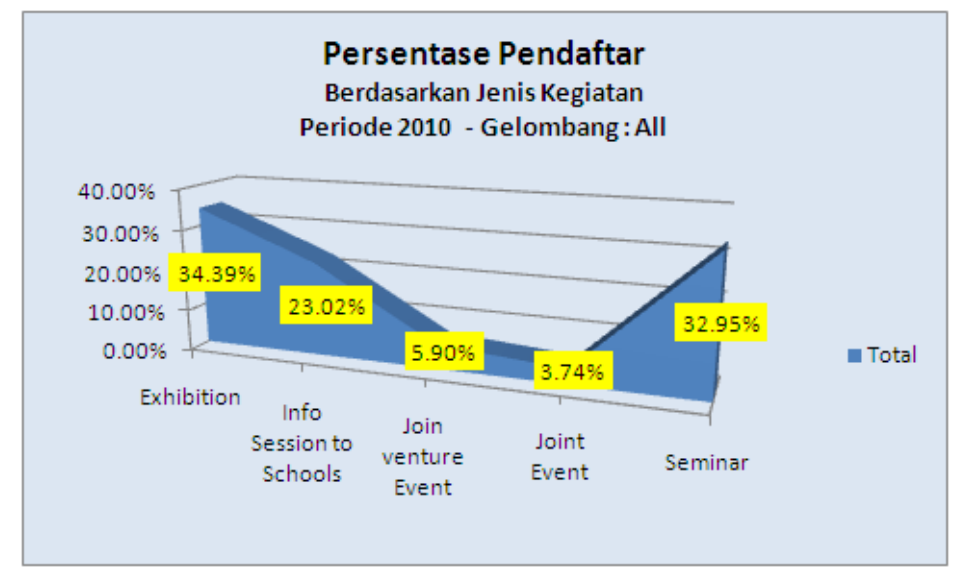

Gambar 12. Rancangan antar muka informasi persentase pendaftar berdasarkan jenis kegiatan.

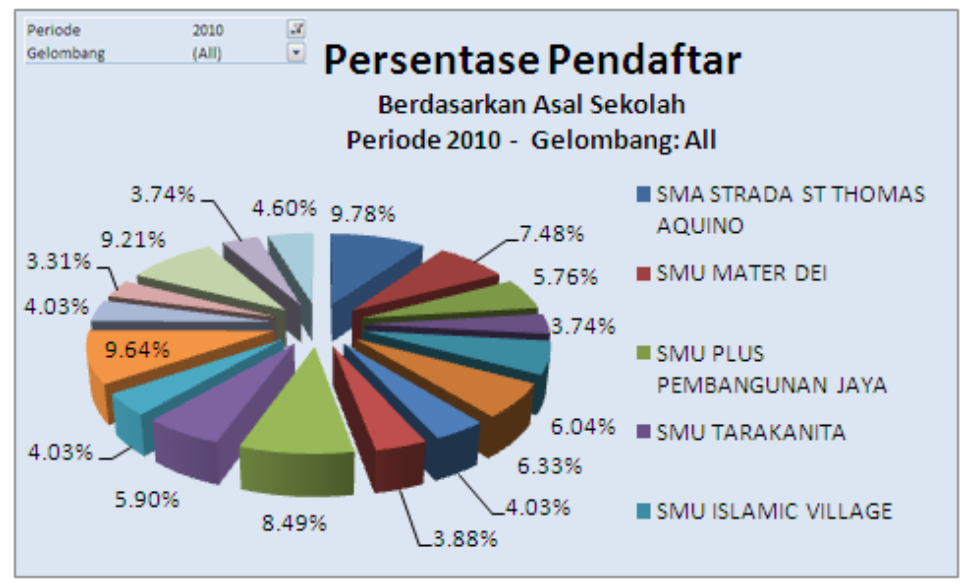

Gambar 13. Rancangan antar muka informasi persentase pendaftar berdasarkan asal sekolah.

\section{PENUTUP}

Data warehouse dapat digunakan untuk menyimpan data dalam jumlah besar, berpotensi untuk mendapatkan sudut pandang baru dari sebaran data, dan memungkinkan memberikan pelaporan dan jawaban dari pertanyaan pengguna yang bersifat ad hoc, termasuk juga melakukan analisis terhadap record kegiatan pemasaran untuk mendukung pengambilan keputusan pada bagian pemasaran perguruan tinggi.

Proses transformasi dari database yang menyimpan data transaksi akademik siswa mampu memindahkan data penting yang berguna bagi perguruan tinggi untuk melakukan analisis. Star Schema yang telah dirancang dapat memenuhi fungsinya sebagai suatu tempat penampungan data yang memungkinkan para pengambil keputusan untuk pergi hanya ke satu tempat untuk mengakses seluruh data yang ada tentang suatu masalah.

Dalam pembangunan data warehouse pemasaran perguruan pinggi terdapat beberapa tahapan yang dapat dipenuhi untuk memastikan agar pengembangannya mencapai hasil sebagaimana yang diinginkan. Secara garis besar, tahapan-tahan tersebut meliputi: analisis data yang terkait dengan pemasaran perguruan tinggi dan desain serta pembangunan data warehouse. 
Dimensi yang dapat digunakan dalam perancangan data warehouse pemasaran perguruan tinggi adalah dimensi gelombang, propinsi, kota, waktu, periode, jenis kegiatan, sekolah, semester dan jurusan. Sedangkan fakta yang dapat digunakan dalam perancangan data warehouse pemasaran perguruan tinggi adalah: fakta kegiatan pemasaran dan promosi, dan fakta kegiatan pendaftaran. Dari fakta-fakta dan dimensi yang ada pada perancangan data warehouse yang digambarkan dalam bentuk grafikal, didapatkan informasi-informasi yang bermanfaat bagi bagian pemasaran perguruan tinggi untuk menentukan strategi pemasaran yang efektif.

\section{DAFTAR PUSTAKA}

Mallach, Efrem G. (2000). Decision Support and Data Warehouse Systems. New York: McGraw-Hill.

Rizal, Furinto, Asnan. (2009). Marketing Reloaded. Jakarta: Salemba Empat.

Rudy, Miranda, E., Suryani, E. (2010). Pembangunan Model Business Intelligence untuk Memaksimalkan Proses Pemasaran Perguruan Tinggi. Laporan Penelitian Hibah Bersaing. Jakarta: Binus University.

Teh Ying Wah, Ng Hooi Peng, Ching Sue Hok. (2007). Building Data Warehouse. Proceedings of the 24th South East Asia Regional Computer Conference, Bangkok, Thailand.

Vercellis, Carlo (2009). Business Intelligence: Data Mining and Optimization for Decision Making. Chichester: John Wiley and Sons. 